\title{
Etnomatematika pada sumur purbakala Desa Kaliwadas Cirebon dan kaitannya dengan pembelajaran matematika di sekolah
}

\author{
Muchamad Subali Noto *, Siska Firmasari, Mohammad Fatchurrohman \\ Jurusan Pendidikan Matematika, Universitas Swadaya Gunung Jati. \\ Jalan Perjuangan No. 1, Sunyaragi, Kesambi, Kota Cirebon 45132, Indonesia. \\ * Corresponding Author. E-mail: msubalinoto@ fkip-unswagati.ac.id \\ Received: 20 October 2016; Revised: 14 March 2018; Accepted: 31 December 2018
}

\begin{abstract}
Abstrak
Tujuan penelitian ini adalah untuk mengetahui kontribusi aspek-aspek matematika pada sumur purbakala, sejarahnya, proses berpikir matematis dalam pembuatan sumur, dan proses pembelajaran matematika di sekolah. Hasil penelitian ini disajikan dalam bentuk kualitatif untuk mendeskripsikan tentang sejarah sumur purbakala. Bentuk bangunan sumur menggambarkan sebuah bangun datar seperti segitiga, segilima, persegi panjang, jajar genjang, trapesium, lingkaran, dan bangun ruang seperti balok dan tabung, yang merupakan aspek-aspek matematika pada materi geometri. Proses pembuatan sumur yang berbentuk lingkaran dapat dilakukan dengan segi- $n$ yang didekati oleh limit $n$ menuju tak hingga yang dilihat dari banyaknya batu bata pada susunan pertama dan banyaknya susunan pada pembuatan sumur. Hasil penelitian ini juga berkaitan dengan proses pembelajaran matematika di sekolah, seperti materi segitiga dan segiempat di SMP serta aturan sinus dan cosinus di SMA. Diharapkan hasil penelitian ini dapat dijadikan bahan ajar pada jenjang sekolah menengah ataupun referensi untuk penelitian lain di bidang budaya dan matematika.
\end{abstract}

Kata Kunci: etnomatematika, sumur purbakala, pembelajaran matematika

\section{Ethnomathematics at the sumur purbakala Kaliwadas Village of Cirebon and relationship with mathematics learning in school}

\begin{abstract}
The purpose of this research is to know the mathematical aspects of sumur purbakala, its history, the process of mathematical thinking in the making of well, and the process of learning mathematics in school. The results of this research are presented in qualitative form to describe the history of the sumur purbakala. The shape of the building is constructed like a triangle, a pentagon, a rectangle, a parallelogram, a trapezoid, a circle, and a space-building like beams and tubes, which are the mathematical aspects of the material geometry. The process of making a well in the form of a circle can be done with the n-segments approximated by the boundary $n$ to the not until seen from the number of bricks in the first order and the number of arrangements on the well-making. The results of this study are also related to the process of learning mathematics in schools, such as triangle and quadrilateral materials in junior high and the rules of sinus and cosine in high school. It is expected that the results of this study can be used as teaching materials at the level of the school and references to other research in the field of culture and mathematics.
\end{abstract}

Keywords: ethnomathematics, sumur purbakala, mathematics learning

How to Cite: Noto, M., Firmasari, S., \& Fatchurrohman, M. (2018). Etnomatematika pada sumur purbakala Desa Kaliwadas Cirebon dan kaitannya dengan pembelajaran matematika di sekolah. Jurnal Riset Pendidikan Matematika, 5(2), 201-210. doi:https://doi.org/10.21831/jrpm.v5i2.15714

Permalink/DOI: https://doi.org/10.21831/jrpm.v5i2.15714

\section{PENDAHULUAN}

Matematika merupakan ilmu dasar dari segala ilmu, baik aspek penalaran maupun terapannya berperan penting dalam upaya penguasa- an ilmu pengetahuan, teknologi, dan budaya. Matematika merupakan salah satu ilmu pengetahuan di bidang pendidikan yang sering diterapkan di masyarakat, tetapi dalam kenyataannya 
sebagian besar dari mereka kurang menyadari keberadaannya. Mereka menganggap bahwa matematika hanyalah suatu ilmu hitung yang diperoleh saat pembelajaran di sekolah. Menurut Syahrin, Turmudi, dan Puspita (2015), matematika merupakan suatu konsep yang abstrak dan sulit, oleh karena itu kebanyakan siswa tidak menyukainya. Sedangkan Rosa dan Orey (2011), menjelaskan bahwa matematika yang dipelajari di sekolah sebagai mata pelajaran tidak terkait dengan budaya yang secara umum pembelajarannya meliputi fakta-fakta, konsep, dan materi. Oleh karena itu, walaupun matematika dianggap sebagai ilmu pengetahuan yang sempurna dengan kebenaran yang objektif tetapi dirasakan jauh dari realitas kehidupan sehari-hari.

Kehidupan setiap orang dalam menyesuaikan diri dengan lingkungan dan mempertahankan kelangsungan hidupnya sangat bergantung pada proses dan kemampuan berpikirnya. Menurut Melhem dan Isa (2013) kemampuan berpikir sangatlah diperlukan, karena melingkupi pengetahuan terbaru dengan cakupan yang luas. Pemahaman yang diperoleh ketika belajar matematika dapat menumbuhkan kemampuan berpikir, yaitu berpikir matematis. Berpikir matematis inilah yang diperlukan untuk memperoleh manfaat matematika dalam kehidupan sehari-hari sekaligus untuk meningkatkan kemampuan berpikir ke tingkat yang lebih tinggi. Menurut Dewi dan Kusumah (2014) kemampuan berpikir matematis tingkat tinggi melingkupi kemampuan pemecahan masalah matematis, penalaran matematis, komunikasi matematis, dan koneksi matematis. Sedangkan menurut Nfon (2015), cara merasakan keberadaan matematika yang sesungguhnya dapat dilihat dari pengalaman setiap orang dalam menunjukkan bahwa pemikiran matematis selalu melekat pada kehidupan mereka. Oleh karena itu, berpikir matematis penting dalam mengimplementasikan ilmu matematika dalam kehidupan sehari-hari.

Implementasi berpikir matematis dalam kehidupan nyata tidak akan terealisasi jika tidak adanya objek yang dapat dijadikan bahan untuk meningkatkan kemampuan berpikir matematis siswa. Contoh objek tersebut adalah budaya, menurut Hisrich, Bucar, dan Oztark (2003) budaya diidentifikasi sebagai faktor penting yang mempengaruhi pemahaman dan interpretasi proses penilaian, pengembangan, pelaksanaan, dan elemen serta fungsi penilaian lainnya, karena budaya sesuatu yang nyata dalam kehidupan. Karakter bangsa tidak bisa terlepas dari nilai-nilai suatu budaya, karena nilai-nilai budaya tersebut pastinya tidak terlepas dari budaya itu sendiri. Menurut Joy dan Kolb (2008), budaya dioperasionalkan sebagai identitas suatu negara atau kewarganegaraan subjek. Indonesia dikenal memiliki keberagaman budaya. Salah satu contoh kebudayaan yaitu peninggalan masa lalu yang merupakan kekayaan bangsa yang tak ternilai harganya. Semakin langka suatu peninggalan bersejarah semakin tinggi nilainya. Peninggalan bersejarah sangat bermanfaat sebagai bahan studi atau penelitian, di samping juga dapat dijadikan sebagai objek wisata.

Matematika dan kebudayaan adalah sesuatu yang tidak dapat dihindari dalam kehidupan sehari-hari. Matematika merupakan sumber ilmu dan kebutuhan utama tiap individu, sementara itu budaya adalah kesatuan utuh dan pedoman tingkah laku yang menyeluruh dalam masyarakat serta berperan penting dalam menumbuhkan nilai luhur bangsa. Menurut Ubayanti, Lumbantobing, dan Manurung (2016), matematika adalah bagian dari kebudayaan, karena matematika dan pembelajarannya menjadikan matematika milik seluruh umat manusia, dan karenanya matematika bersifat universal. Dengan demikian, pembelajaran matematika berbasis budaya dapat dijadikan media bagi siswa untuk mentransformasikan temuannya ke dalam bentuk dan prinsip yang kreatif terkait alam, yang merupakan perancangan pengalaman belajar sekaligus strategi penciptaan lingkungan belajar yang mengintegrasikan budaya sebagai bagian dari proses pembelajaran.

Salah satu model dan strategi pembelajaran yang baik dalam memahami dan mempelajari matematika sekaligus menumbuhkan rasa cinta pada budaya adalah dengan mempelajari etnomatematika. Menurut D'Ambrosio (2001), etnomatematika merupakan program penelitian terkait sejarah dan filsafat matematika, dengan maksud pedagogis, memusatkan pada seni dan teknik [tics] menjelaskan, memahami serta mengatasi [mathema] lingkungan sosial-budaya yang berbeda [ethno]. Sedangkang menurut Hardingdekam (2007), etnomatematika adalah istilah yang diciptakan untuk menjelaskan bahwa setiap orang dapat menggunakan dan belajar matematika. Dengan demikian, penerapan etnomatematika sebagai suatu pendekatan pembelajaran merupakan cara lain untuk menyampaikan matematika secara lebih menarik. Jadi, dapat disimpulkan bahwa etnomatematika adalah matematika yang tumbuh dan berkembang serta dipengaruhi oleh budaya.

Banyak penelitian etnomatematika yang sudah dilakukan, diantaranya oleh Paraide (2008) 
yaitu penomoran pada budaya Tolai di Papua New Guinea, Sternstein (2008) yaitu matematika pada kebudayaan Dan di Liberia dan lain sebagainya. Keanekaragaman budaya yang ada di Indonesia dari Sabang sampai Merauke merupakan aset yang berharga dan tidak ternilai harganya bagi negara, sehingga harus tetap dipertahankan dan terus dilestarikan. Keanekaragaman budaya sudah menjadi bahan kajian, diantaranya oleh Puspadewi dan Putra (2014) yaitu teselasi pada kerajinan anyaman Bali, Arisetyawan, Suryadi, Herman dan Rahmat (2016) yaitu matematika pada kebiasaan masyarakat BaduyBanten, dan lain sebagainya. Cirebon termasuk salah satu daerah yang ada di Indonesia yang kaya akan budaya. Budaya tersebut melingkupi agama, bangunan, bahasa daerah, pakaian tradisional, alat dan jenis musik, pesona alam, dan lain sebagainya. Di Cirebon sudah ada penelitian terkait etnomatematika yang telah dilakukan, diantaranya oleh Syahrin, Turmudi, dan Puspita (2015) yaitu modulo pada kalender islam di Kesepuhan Cirebon, dan Anggara (2016) yaitu eksplorasi etnomatematika pada ragam hias Batik Trusmi Cirebon. Salah satu bentuk budaya yang ada di Cirebon dan belum diteliti adalah Situs Tukmudal Awal Tirta Kencana Biru yang lebih dikenal dengan Sumur Purbakala di Desa Kaliwadas Cirebon. Dilihat dari hasil observasi di Sumur Purbakala dan wawancara terkait proses pembelajaran di sekolah juga, guru belum mengaitkan masalah matematika dengan budaya sebagai contoh di kehidupan nyata.

Tujuan penelitian ini untuk mengangkat unsur etnomatematika dari Sumur Purbakala di Desa Kaliwadas Cirebon dengan alasan ingin mengetahui aspek-aspek matematika yang berkaitan dengan materi geometri dan bagaimana proses berpikir matematis masyarakat pada proses pembuatan sumur serta mengetahui sejarah yang ada sekaligus melestarikan budaya asli Cirebon.

\section{METODE}

Berdasarkan definisi mengenai etnomatematika, jenis penelitian yang digunakan dalam penelitian ini adalah penelitian kualitatif. Permasalahan yang akan dikaji oleh peneliti adalah masalah yang berkaitan dengan unsur sosial. Oleh karena itu, metode yang digunakan oleh penulis dalam penelitian ini adalah metode deskriptif dengan pendekatan etnografi dan tipe studi kasus.

Tempat pelaksanaan penelitian berada di Sumur Purbakala, Blok Tukmudal, Desa Kali- wadas, Kecamatan Sumber, Kabupaten Cirebon. Sedangkan waktu pelaksanaan penelitian dilaksanakan selama 5 bulan, terhitung dari Bulan Maret sampai dengan Bulan Juli 2017. Subjek dalam penelitian ini adalah Sumur Purbakala, dan narasumber yang terkait, Sedangkan objek penelitian yang ditinjau dari penelitian ini adalah kajian dalam sejarah Sumur Purbakala, aspek-aspek matematika pada materi geometri, dan proses berpikir matematis masyarakatnya.

Instrumen penelitian digunakan sebagai alat untuk mempermudah penelitian dalam menjawab permasalahan yang berkaitan dengan budaya dan matematika yang ada di Sumur Purbakala. Pada penelitian ini instrumen yang digunakan yaitu: peneliti sebagai instrumen utama, pedoman observasi, pedoman dokumentasi, dan pedoman wawancara.

Teknik pengumpulan data merupakan cara yang digunakan peneliti untuk mendapatkan data dalam suatu penelitian. Pada penelitian ini peneliti memilih jenis penelitian kualitatif, maka data yang diperoleh haruslah mendalam, jelas dan spesifik. Pada penelitian ini, peneliti menggunakan teknik pengumpulan data dengan cara observasi, wawancara, studi pustaka, dan dokumentasi.

Pada penelitian ini menggunakan pendekatan etnografi. Dalam penelitian ini dipilih beberapa orang sebagai narasumber untuk menjawab permasalahan yang ada sesuai dengan tujuan penelitian, diantaranya pengurus Sumur Purbakala, masyarakat Desa Kaliwadas, dan tukang gali sumur. Untuk mencapai tujuan tersebut, langkah-langkah yang digunakan dengan pendekatan etnografi adalah sebagai meliputi:

\section{Melakukan Kegiatan Pendahuluan}

Pada tahapan pendahuluan dilakukan dengan cara memahami secara mendalam tentang kebudayaan tersebut dilanjutkan dengan menentukan subjek penelitian. Kemudian melakukan pengamatan awal dengan cara mengamati aspekaspek matematika dan proses berpikir matematis masyarakat sekaligus sejarah yang ada di Desa Kaliwadas Cirebon serta peneliti perlu meminta izin dari otoritas lembaga atau kelompok yang akan diteliti.

\section{Membuat Instrumen}

Tahap persiapan yang dilakukan adalah membuat pedoman observasi, dokumentasi dan wawancara. Instrumen penelitian dibuat berdasarkan pengamatan awal peneliti mengenai kebudayaan yang ada dan aspek-aspek matematika 
yang terkait serta proses berpikir matematis masyarakatnya sekaligus sejarah yang ada di Sumur Purbakala. Pedoman observasi digunakan sebagai pedoman peneliti saat kegiatan penelitian berlangsung, pedoman dokumentasi digunakan sebagai bukti fisik saat penelitian, dan pedoman wawancara digunakan sebagai alat yang dijadikan sumber data yang didapat dari narasumber untuk menjawab berbagai pertanyaan-pertanyaan yang akan diajukan peneliti.

Pelaksanaan

Dalam etnografi, pengumpulan data dilakukan dengan prosedur beragam (multiple procedures), dan intensitas prosedur-prosedur itu bervariasi sesuai tipe etnografi yang dilakukan. Dalam penelitian studi kasus, peneliti dapat mengumpulkan data melalui wawancara, pengamatan, dokumen, dan rekaman-rekaman audiovisual. Pengumpulan data dilakukan dengan cara observasi langsung ke Sumur Purbakala sekaligus mengamati dan mengikuti kegiatan yang ada disana serta melakukan wawancara secara mendalam (deep interview) kepada beberapa orang seperti pengurus Sumur Purbakala, masyarakat Desa Kaliwadas, dan tukang gali sumur. Tahap ini dilakukan sampai dengan peneliti mendapatkan data/informasi sesuai dengan jadwal yang telah ditentukan dan dapat dijadikan sumber data untuk menjawab rumusan masalah yang ada dan mencapai tujuan penelitian yang diharapkan.

\section{Verifikasi Data}

Pada tahap ini yaitu memverifikasi hasil pengumpulan data yang telah didapat selama penelitian di Sumur Purbakala sesuai dengan jenis dan bentuknya agar dapat dipahami dengan mudah ketika menganalisis data, baik verifikasi data hasil observasi, dokumentasi dan wawancara kepada dua dosen pendidikan matematika. Jika verifikasi data sudah valid dapat dilanjutkan ke tahap selanjutnya tapi jika belum valid maka akan direvisi dengan mengumpulan data ulang.

\section{Analisis Data}

Tahap analisis data dilakukan dengan cara mengelompokkan data hasil penelitian pada saat observasi dan wawancara serta mengorganisir sumber data sesuai dengan fokus kajian masalah dan tujuan penelitian, yaitu mengidentifikasi aspek-aspek matematika pada materi geometri dan menunjukkan proses berpikir matematis masyarakat yang ada sekaligus sejarah yang ada pada Sumur Purbakala. Analisis ini bertujuan untuk mendeskripsikan etnomatematika yang ada pada Sumur Purbakala di Desa Kaliwadas Cirebon.

\section{Membuat Kesimpulan}

Pada tahap ini peneliti mengemas informasi/data setelah dianalisis untuk mengetahui aspek-aspek matematika pada materi geometri dan proses berpikir matematis masyarakatnya serta sejarah yang ada di Sumur Purbakala untuk ditarikkesimpulan sesuai dengan rumusan masalah yang ada.

\section{HASIL DAN PEMBAHASAN}

Sumur Purbakala merupakan hasil karya Ki Danuarsi dan Ki Danusela. Sumur tersebut merupakan sumber air yang berbentuk lubang yang berukuran besar dan merupakan sumur yang pertama ada di daerah Cirebon, sudah ada sebelum Cirebon berdiri. Tujuan pembuatan Sumur Purbakala yaitu untuk sumber kehidupan bagi masyarakat yang ada di lingkungan sekitar, sedangkan untuk manfaat sumurnya tergantung ikhtiar tiap orang kepada Allah SWT, Sumur Purbakala hanya dijadikan sarananya saja. Sumur Purbakala merupakan cagar budaya yang dibuat oleh leluhur yang sudah berjuang sejak dahulu.

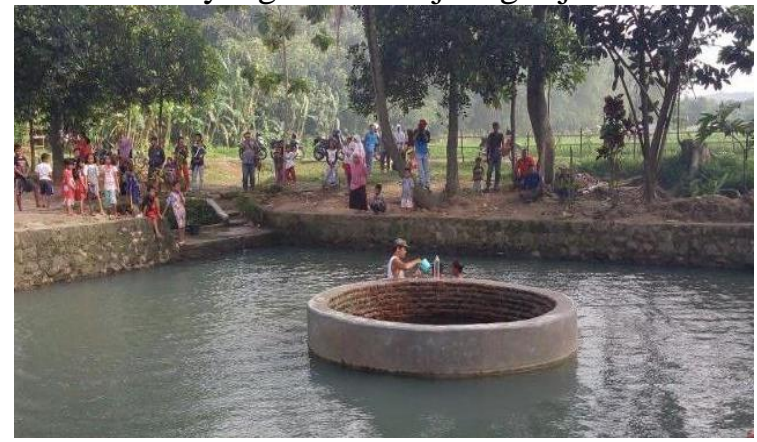

Gambar 1. Situs Balong Tukmudal Awal Tirta Kencana Biru

Setelah ditemukannya sumur-sumur yang ada di lahan seluas $1.300 \mathrm{~m}^{2}$ tersebut, dijadikanlah tempat itu sebagai tempat yang sakral dalam naungan Keraton Kanoman Cirebon yang diberi nama Situs Tukmudal Awal Tirta Kencana Biru. Dalam situs tersebut terdapat 9 sumur, 7 sumur berada di dalam balong dan 2 sumur lainnya berada di luar. Kesembilan sumur tersebut diberi nama: Sumur Tukmudal Awal Tirta Kencana Biru, Sumur Jalatunda, Sumur Kemulyan, Sumur Balong Sepuh, Sumur Anom, Sumur Kepuntren, Sumur Kejayan, Sumur Belik Kalimaya, Sumur Plawangan

Di Balong sendiri ada 7 sumur yang mengandung banyak arti dan filosofi, kenapa hari ada 7 ? kembang ada 7 ? langit 7 lapisan? bumi 7 
lapisan? dan lain sebagainya. Tujuan pengunjung dari berbagai profesi seperti petani, pedagang, pengusaha, pejabat ataupun yang lainnya di sumur tersebut yaitu setiap orang ingin mengetahui kelanjutan hidupnya kemana? mau jadi apa? Di luar balong sendiri ada 2 sumur yaitu Sumur Belik Kalimaya dan Sumur Plawangan. Sumur Plawangan memiliki arti jika kita sudah berada diatas dan tujuan tercapai, maka jangan sombong dan lupa dengan Allah SWT. Di situs terdapat salah satu sumur yaitu Sumur Tukmudal Awal Tirta Kencana Biru yang merupakan sumber air terbesar yang ada di balong. Air pada sumur tersebut dapat langsung diminum dan berwarna biru yang merupakan keajaiban dari Allah SWT.

Di Balong yang ada di Situs Tukmudal Awal Tirta Kencana Biru tidak hanya ada sumursumur saja, ada juga lintasan yang memiliki arti tersendiri. Lintasan tersebut mempunyai makna dan filosofi sesuai dengan kehidupan manusia. Lintasan tersebut merupakan jalan penghubung setiap sumur agar orang mudah mendatangi semua sumur yang ada di balong tersebut.

Sumur Purbakala bukan hanya sekedar sumur yang dikeramatkan dan dijadikan sumber air saja, di tempat tersebut banyak kegiatan yang sudah ada dari dulu dan dilestarikan sampai sekarang, serta ada juga kegiatan yang baru ada setelah Sumur Purbakala diresmikan. Kegiatan tersebut merupakan warisan dari para leluhur untuk masyarakatnya, seperti: tawasulan yang merupakan kegiatan spiritual dan bertujuan untuk mendoakan arwah-arwah para leluhur yang telah tiada, pengurasan yang merupakan kegiatan rutin tahunan yang dilakukan oleh masyarakat untuk membersihkan air yang ada di area Situs Tukmudal Awal Tirta Kencana Biru, dan luru berkah yang merupakan kegiatan harian yang dilakukan masyarakat dan memiliki tujuan tertentu sesuai kehendak atau keinginan masingmasing orang.

\section{Etnomatematika pada Sumur Purbakala}

Dilihat dari sejarahnya, keberadaan Sumur Purbakala yang sempat hilang dari peradaban membuat bangunan tersebut dibangun kembali sesuai dengan gambaran dulunya. Sumur Purbakala merupakan bangunan yang unik dilihat dari segi keseluruhan bangunannya, seperti balong, lintasan, dan sumur-sumurnya.

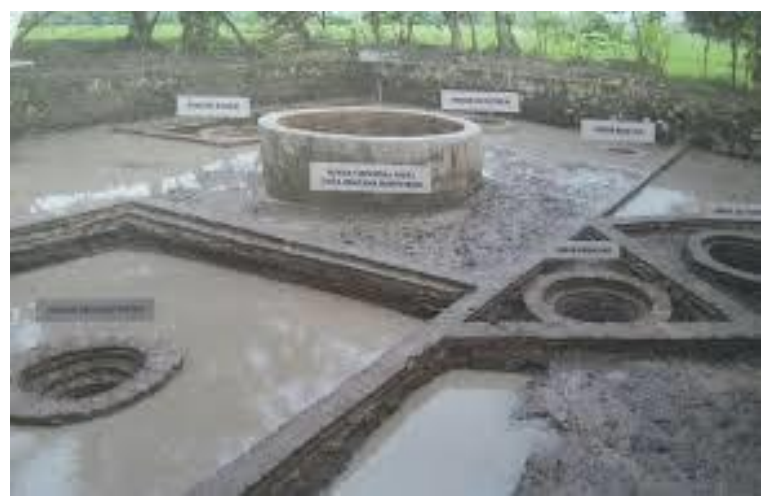

Gambar 2. Kondisi Balong Sumur Purbakala saat Dikuras

Dilihat dari denah bangunan yang tampak pada Gambar 3, area Sumur Purbakala tersusun atas beberapa bentuk bangun datar dan bangun ruang seperti persegi panjang, lingkaran, segitiga, trapesium, jajar genjang, segilima, balok, dan tabung. Walaupun belum ada yang tahu, apakah dulu para leluhur yang membuat area Sumur Purbakala ini sudah mengenal bangun datar maupun ruang.

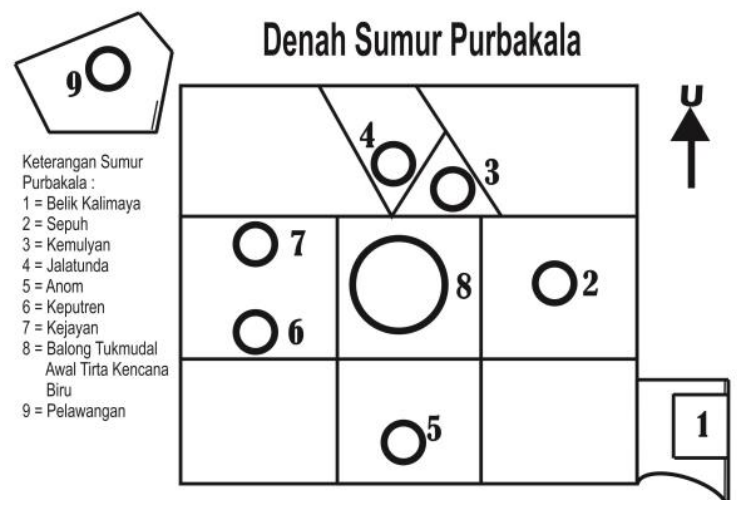

Gambar 3. Denah Sumur Purbakala

Jika dilihat dari aspek geometri yang terdapat pada denah hasil pengukuran didapat beberapa bentuk seperti terlihat pada Gambar 4 .

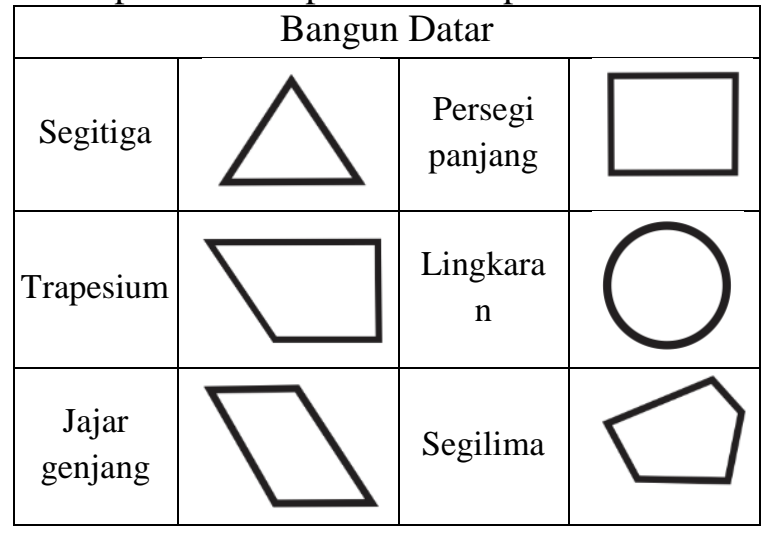

Gambar 4. Bangun Datar yang Berada pada Sumur Purbakala 
Dari hasil penelusuran juga didapat bahwa balong pada Sumur Purbakala berbentuk balok dan jika dilihat saat kegiatan pengurasan, terlihat jelas sumur tersebut berbentuk tabung. Hal ini dapat dijadikan aspek-aspek geometri lain yang ada pada Sumur Purbakala.

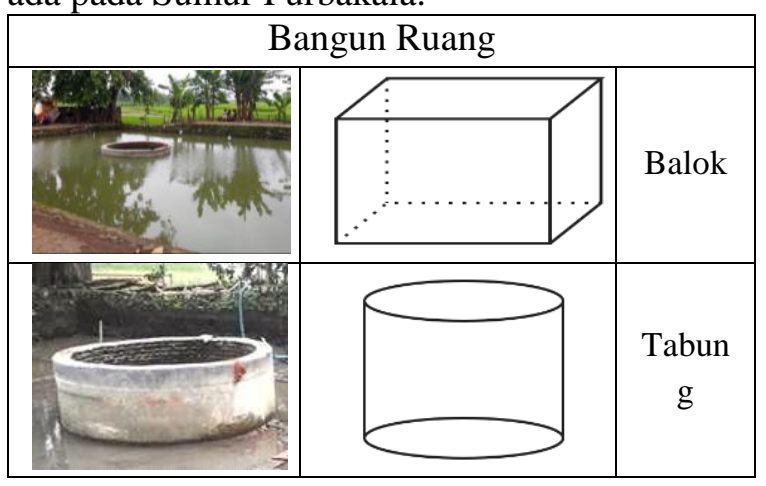

Gambar 5. Bangun Ruang yang Berada pada Sumur Purbakala

Jika dilihat dari konsep titik pusat geometri pada bangun datar, antara balong dan Sumur Tukmudal Awal Tirta Kencana Biru. Dapat diberikan ilustrasi sesuai dengan ukuran yang ada di denah pada Gambar 6.

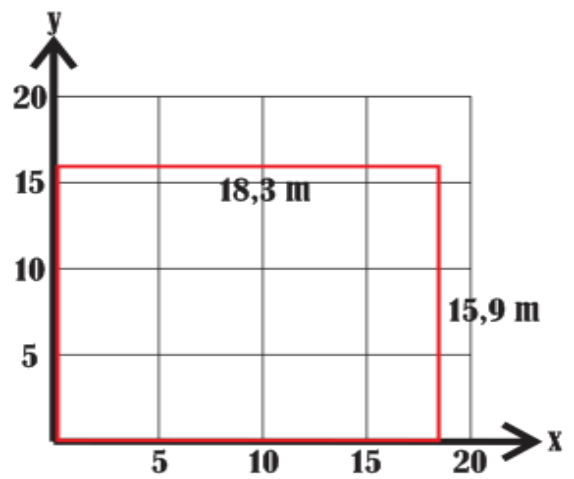

Gambar 6. Representasi Balong pada Diagram Cartesius

Misal garis $x$ merupakan sumbu $x$ dalam satuan meter dan garis $y$ merupakan sumbu $y$ dalam satuan yang sama. Maka didapat panjang suatu bangun persegi panjang itu $x_{1}=18,3$ meter dan $y_{1}=15,9$ meter. Karena bangun datar tersebut berbentuk persegi panjang, maka rumus untuk mencari titik pusatnya yaitu:

Dengan mensubstitusikan nilai dari $x_{1}$ dan $y_{1}$ didapat:

$$
\begin{aligned}
& x_{0=\frac{18,3}{2}}=9,15 \\
& y_{0}=\frac{15,9}{2}=7,95
\end{aligned}
$$

Diperoleh koordinat titik pusatnya yaitu $(9,15 ; 7,95)$, yang dimana jika dilihat pada denah yang terdapat pada Gambar 7 berupa,

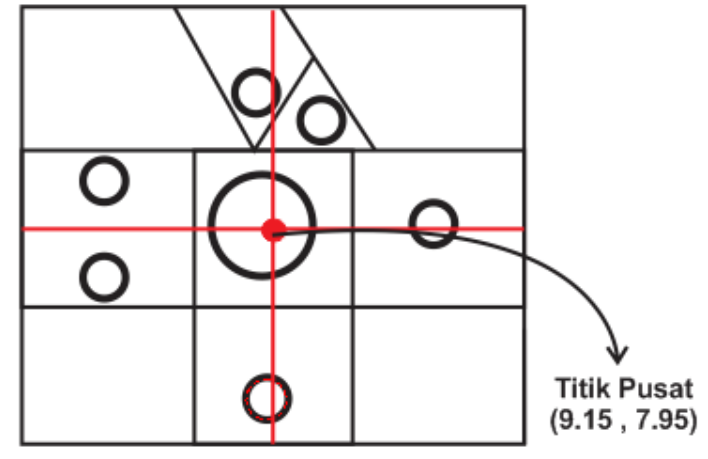

Gambar 7. Titik Pusat pada Balong

Titik pusat $(9,15 ; 7,95)$ merupakan titik pusat persegi panjang atau balong. Dilihat dari denah, titik pusat tersebut terdapat pada Sumur Tukmudal Awal Tirta Kencana Biru. Oleh sebab itu, sumur tersebut merupakan pusat sumber mata air yang berada pada balong dan menjadi bukti bahwa hasil wawancara tentang sumber mata air terbesar berada pada Sumur Tukmudal Awal Tirta Kencana Biru adalah benar.

Selain aspek-aspek matematika pada geometri yang menyangkut bangun datar dan bangun ruang, masih ada lagi hubungan matematika dengan Sumur Purbakala yaitu tentang cara berpikir matematis masyarakatnya dalam hal pembuatan sumur yang berbentuk lingkaran.

Jika dilihat pembahasan tersebut, cara pembuatan sumur menggunakan batu bata dapat diilustrasikan seperti pada Gambar 8 .
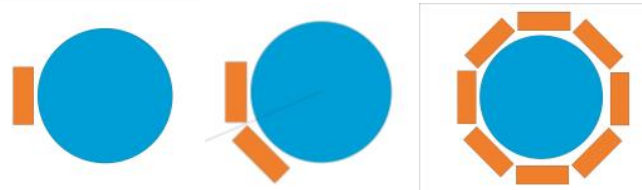

Gambar 8. Peletakan Batu Bata pada Pembuatan Sumur

Jika lingkaran berwarna biru merupakan suatu lubang pembuatan sumur dan persegi panjang berwarna coklat merupakan batu bata yang diletakkan mengelilingi sumur. Maka gambaran susunan pertama batu bata seperti gambar

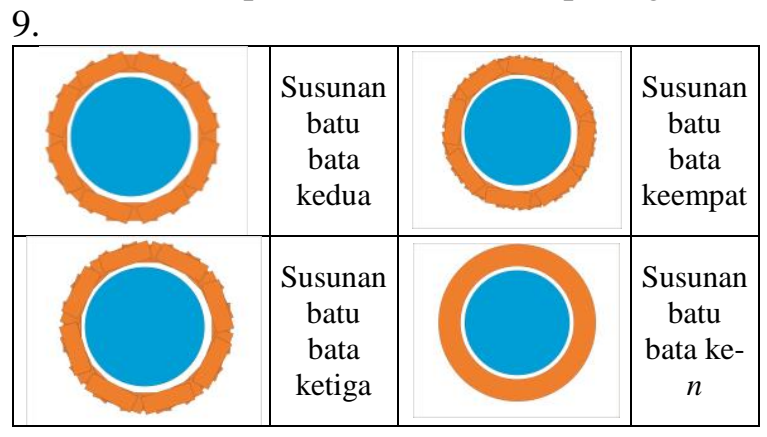

Gambar 9. Susunan Batu Bata 
Jika diperhatikan, batu bata yang tersusun semakin banyak semakin mirip dengan lingkaran. Disinilah konsep matematika pada materi segi-n dan ketakhinggaan menggunakan limit yang diterapkan dengan memperhitungkan banyaknya segitiga sama kaki yang memiliki luas yang sama.

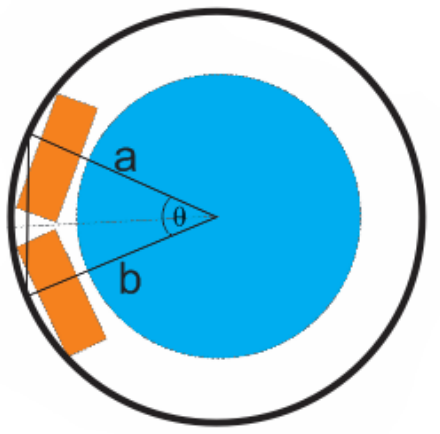

Gambar 10. Representasi Peletakkan Batu Bata pada Segi- $n$

Menggunakan rumus luas segitiga pada trigonometri dalam menentukan luas dari segi-n, sebagai berikut:

$$
L=\frac{1}{2} a b \sin \theta
$$

Dikarenakan nilai $a=b=$ jari-jari $=r$, dan luas segitiga tersebut sebanyak $n$ serta terbatas pada suatu lingkaran, maka rumusnya berubah menjadi,

$$
L=\frac{n}{2} r^{2} \sin \frac{2 \pi}{n}
$$

Nilai $n$ yang semakin jauh semakin mendekati tak hingga $(\infty)$. Dalam penyelesaian kasus tersebut harus menggunakan konsep limit tak hingga, maka

$$
\begin{aligned}
\lim _{n \rightarrow \infty} L & =\lim _{n \rightarrow \infty}\left[\frac{n}{2} r^{2} \sin \frac{2 \pi}{n}\right] \\
& =\frac{1}{2} r^{2} \lim _{n \rightarrow \infty}\left[n \sin \frac{2 \pi}{n}\right]
\end{aligned}
$$

Bentuk $\lim _{n \rightarrow \infty}\left[n \sin \frac{2 \pi}{n}\right]$ merupakan limit fungsi trigonometri. Sehingga limit tersebut perlu diuraikan, caranya dengan mengalikan $\frac{\frac{2 \pi}{n}}{\frac{2 \pi}{n}}$ pada limitnya.

$$
\begin{aligned}
& \lim _{n \rightarrow \infty} L=\frac{1}{2} r^{2} \lim _{n \rightarrow \infty}\left[n \sin \frac{2 \pi}{n} \cdot \frac{\frac{2 \pi}{n}}{\frac{2 \pi}{n}}\right] \\
& \lim _{n \rightarrow \infty} L=\frac{1}{2} r^{2} \lim _{n \rightarrow \infty}\left[n \frac{2 \pi}{n} \cdot \frac{\sin \frac{2 \pi}{n}}{\frac{2 \pi}{n}}\right]
\end{aligned}
$$

$$
\begin{aligned}
\lim _{n \rightarrow \infty} L & =\frac{1}{2} r^{2} \lim _{n \rightarrow \infty}[2 \pi .1] \\
\lim _{n \rightarrow \infty} L & =\frac{1}{2} r^{2} \lim _{n \rightarrow \infty}[2 \pi] \\
\lim _{n \rightarrow \infty} L & =\frac{1}{2} r^{2} 2 \pi \\
\lim _{n \rightarrow \infty} L & =\pi r^{2} \\
\lim _{n \rightarrow \infty} L & =\text { rumus luas lingkaran }
\end{aligned}
$$

Dilihat dari hasil yang didapat, luas segi-n sebanyak n kali jika didekatkan dengan konsep limit menjadikan nilai akhirnya sama dengan rumus luas lingkaran. Dapat disimpulkan bahwa rumus luas segi-n sebanyak $n$ kali dapat mendekati nilai dari luas suatu lingkaran.

\section{Etnomatematika Sumur Purbakala dalam Pembelajaran Matematika}

Aspek-aspek matematika pada Sumur Purbakala dapat digunakan dalam pembelajaran matematika, karena dalam pengajaran di sekolah, materi matematika seperti geometri dan luas segitiga dengan aturan trigonometri yang didekati suatu limit dapat diterapkan. Pada pengajaran matematika di sekolah, materi geometri berada pada jenjang Sekolah Menengah Pertama (SMP) dan materi luas segitiga dengan aturan trigonometri ada pada jenjang Sekolah Menengah Atas (SMA). Karena mengandung aspek-aspek matematika, tentunya hasil dari temuan-temuan yang ada pada Sumur Purbakala ini dapat dijadikan dan dimanfaatkan sebagai sumber belajar dalam pembelajaran di kelas.

\section{Materi Sekolah Menengah Pertama (SMP)}

Dilihat dari denah yang ada di Sumur Purbakala pada Gambar 11, dengan mengambil sampelnya yaitu suatu balong dan lintasan yang ada pada balong. Dapat terlihat beberapa aspek matematika pada materi bangun segitiga dan segiempat di Sumur Purbakala, diantaranya yaitu: persegi, persegi panjang, belah ketupat, jajargenjang, trapesium, layang-layang, dan segitiga. Guru dapat menge-mas pembelajaran dengan memanfaatkan aspek-aspek matematika ini dengan menyesuaikan pada materi yang dibahas.

Dengan menambahkan beberapa warna dan garis, dapat diseleksi beberapa bangun datar dan akan ditemukan: (a) bangun datar berwarna merah bisa dijadikan bangun datar persegi atau belah ketupat; (b) bangun datar berwarna oranye merupakan persegi panjang; (c) bangun datar berwarna biru dan hijau merupakan trapezium; 
(d) bangun datar berwarna ungu merupakan segitiga; (e) bangun datar berwarna gabungan hijau dan ungu merupakan jajar genjang; (f) bangun datar berwarna gabungan merah dan abu-abu merupakan layang-layang; (g) skala bisa dijadikan cara untuk menghitung luas dan keliling suatu bangun segitiga atau segiempat.

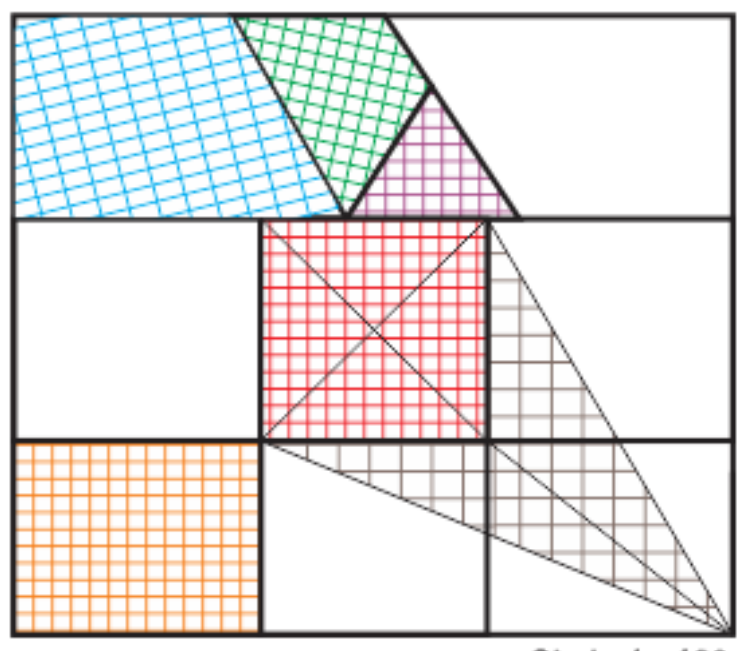

Skala $1: 100$

Gambar 11. Denah Balong dan Lintasan pada Balong

\section{Materi Sekolah Menengah Atas (SMA)}

Dalam proses pembuatan sumur sendiri dapat diterapkan luas segitiga menggunakan aturan sinus dan cosinus. Bentuk lingkaran pada sumur dapat dijadikan patokan dalam mencari luas segitiga yang diperbanyak, sehingga membentuk segi- $n$. Hubungan segi- $n$ dengan proses pembuatan sumur yaitu dengan cara dilihat seberapa banyak batu bata yang ada pada susunan pertama dan berapa banyak susunan yang terjadi. Dengan diketahuinya jari-jari atau diameter suatu sumur, dan mengasumsikan ukuran tiap batu bata sama, maka berapa banyak $n$ dalam segi-n sama dengan banyaknya batu bata pada susunan pertama dan banyaknya susunan batu bata yang terjadi pada pembuatan sumur sama dengan berapa kalinya segi-n pada susunan pertama. Hal ini dikarenakan setiap batu bata pada susunan selanjutnya diletakkan di atas dan di antara 2 batu bata di susunan sebelumnya.

Dengan menerapkan rumus luas segitiga menggunakan aturan sinus, yaitu:

$$
L=\frac{1}{2} a b \sin \theta
$$

Dan karena nilai $a=b=$ jari-jari lingkaran $=r$, dan nilai $\theta$ terbatas pada lingkaran, maka rumus tersebut menjadi sebuah rumus segi- $n$ baru, yaitu,
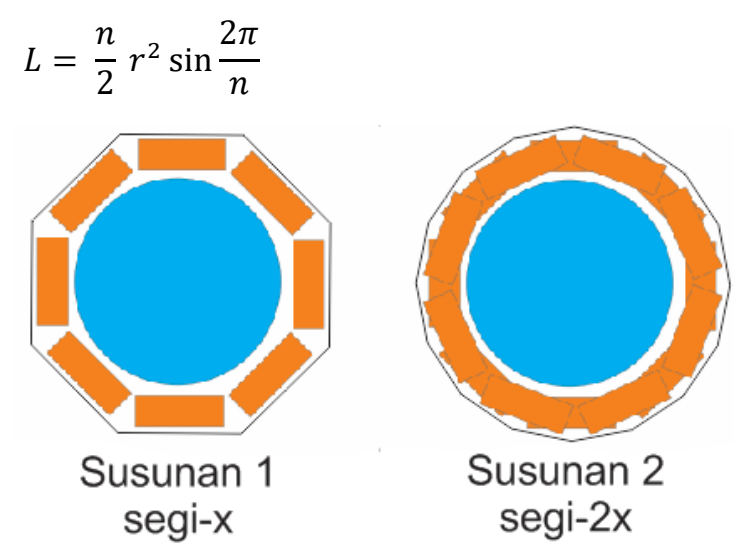

Gambar 12. Segi- $x$ dan Segi- $2 x$

Jika memisalkan banyaknya batu bata pada susunan pertama sebanyak $x$ maka untuk susunan kedua akan menjadi $2 x$ dan yang terbentuk menjadi segi- $2 x$.

Luas susunan pertama $=\frac{x}{2} r^{2} \sin \frac{2 \pi}{x}$

Luas susunan kedua $=\frac{2 x}{2} r^{2} \sin \frac{2 \pi}{2 x}$

Luas susunan ke- $\mathrm{n}=\frac{n x}{2} r^{2} \sin \frac{2 \pi}{n x}$

Dengan permasalahan tersebut, peserta didik dapat diuji kemampuan berpikir kritisnya dalam hal merumuskan pokok-pokok suatu permasalahan. Dalam hal ini, jika diketahui suatu jari-jari atau diameter suatu sumur dan banyaknya batu bata yang diletakan pada susunan pertama serta banyaknya susunan batu bata yang terjadi. Dengan demikian, untuk mencari suatu luas dari bangun datar segi- $n$ tersebut dapat dicari dengan rumus luas susunan ke- $n$. Soal yang terkait proses pembuatan sumur tersebut memenuhi salah satu indikator kemampuan berpikir kritis, yaitu mencari pernyataan yang jelas dari setiap pertanyaan.

Pembelajaran matematika dengan memasukkan etnomatematika yang bersumber dari temuan-temuan yang ada di Sumur Purbakala akan menambah wawasan dan pengetahuan peserta didik mengenai keberadaan matematika pada unsur budaya yang mereka miliki, meningkatkan pemikiran matematis, dan memfasilitasi peserta didik dalam mengaitkan konsep-konsep yang dipelajari dalam situasi dunia nyata.

\section{Pembahasan}

Hasil penelitian menunjukkan bahwa banyak konsep-konsep matematika yang dapat dipelajari dari Sumur Purbakala Desa Kaliwadas Cirebon diantaranya konsep bangun datar, limit, maupun aturan Sinus dan Cosinus. Hal tersebut sekaligus membuktikan bahwa konteks Sumur 
Purbakala tersebut dapat dijadikan sebagai sumber belajar matematika bagi siswa, sehingga pembelajaran matematika menjadi lebih bermakna. Beberapa hasil penelitian terkait etnomatematika misalnya Arisetyawan et al. (2014), Puspadewi dan Putra (2014), Syahrin, Turmudi, dan Puspita (2015) telah melaporkan bahwa penggunaan berbagai konteks nyata dapat menjadikan pembelajaran lebih bermakna bagi siswa.

Salah satu keuntungan lain dari penggunaan konteks Sumur Purbakala dalam pembelajaran matematika yaitu menjadikan matematika menjadi lebih menarik bagi siswa. Selain itu, konteks yang digunakan tersebut juga dapat dijadikan sarana bagi siswa untuk mempelajari peradapanperadapan di masa lalu, sehingga diharapkan akan tumbuh rasa bangga sekaligus kesadaran untuk menjaga dan merawat warisan sejarah tersebut. Hal tersebut sesuai dengan penelitianpenelitian sebelumnya, diantaranya penelitian Rosa dan Orey (2009), Ubayanti, Lumbantobing, dan Manurung (2016) yang telah melaporkan bahwa studi etnomatemtika dapat dimanfaatkan untuk menggali berbagai potensi yang dapat dijadikan sebagai sarana pembelajaran matematika, sehingga siswa menjadi lebih termotivasi dalam pembelajaran matematika.

Penggunaan konteks Sumur Purbakala juga dapat dijadikan sebagai sarana untuk melatih kemampuan berpikir tingkat tinggi siswa. Salah satu karakteristik dari pembelajaran yang melatihkan kemampuan berpikir tingkat tinggi siswa yaitu menggunakan konteks nyata (Apino \& Retnawati, 2017; Jailani, Sugiman \& Apino, 2018). Dengan demikian melalui studi etnometika terkait Sumur Purbakala ini dapat dihasilkan desain pembelajaran yang diharapkan dapat memfasilitasi siswa untuk mengembangkan kemampuan berpikir tingkat tingginya.

\section{SIMPULAN}

Berdasarkan hasil-hasil yang diperoleh, dapat disimpulkan beberapa hal. Pertama, Sumur Purbakala merupakan hasil karya dari leluhur daerah tersebut, yaitu $\mathrm{Ki}$ Danuarsi dan $\mathrm{Ki}$ Danusela. Situs Balong Tukmudal Awal Tirta Kencana Biru di Kaliwadas memiliki 9 sumur yang diberi nama, yaitu: Tukmudal Awal Tirta Kencana Biru, Jalatunda, Kemulyan, Balong Sepuh, Anom, Kepuntren, Kejayan, Belik Kalimaya, Plawangan. Terdapat 3 kegiatan rutin yang dilaksanakan di Sumur Purbakala, yaitu: Tawasulan setiap malam Jum'at, Luru Berkah setiap hari, dan Pengurasan Balong setiap setahun sekali. Kedua, denah Sumur Purbakala memuat beberapa aspek matematika pada materi geometri, khususnya pada bangun datar dan bangun ruang, yaitu: persegi panjang, trapesium, segitiga, jajar genjang, segilima, lingkaran, tabung, dan balok. Dalam perhitungan titik pusat suatu bangun datar, didapat bahwa Sumur Tukmudal Awal Tirta Kencana Biru merupakan sumber air terbesar pada balong di Sumur Purbakala. Ketiga, proses berpikir matematis masyarakat dapat dilihat dari cara pembuatan sumur. Bentuk lingkaran pada sumur tersebut merupakan susunan batu bata seperti bentuk segi$\mathrm{n}$ yang didekati dengan limit untuk $\mathrm{n}$ menuju tak hingga. Keempat, hal-hal yang ditemukan pada denah Sumur Purbakala serta cara pembuatan sumurnya dapat dijadikan sumber belajar matematika di jenjang SMP (segitiga dan segiempat) dan SMA (aturan Sinus dan Cosinus).

\section{DAFTAR PUSTAKA}

Apino, E., \& Retnawati, H. (2017). Developing instructional design to improve mathematical higher order thinking skills of students. Journal of Physics: Conference Series, 812, 1-7. doi:https://doi.org/10.1088/17426596/812/1/012100

Anggara, B. (2016). Pengembangan pembelajaran matematika melalui eksplorasi etnomatematika pada ragam hias batik Trusmi Cirebon. Prosiding Seminar Nasional Matematika dan Pendidikan Matematika FMIPA UNY, 366-382.

Arisetyawan, A., Suryadi, D., Herman, T., \& Rahmat, C. (2014). Study of ethnomathematics: A lesson from the Baduy Culture. International Journal of Education and Research, 2(10), 681-688.

D'Ambrosio, U. (2001). Ethnomathematics: Link between traditions and modernity. Rotterdam, Netherland: Sense Publishers.

Dewi, N. R., \& Kusumah, Y. S. (2014). Developing test of high order mathematical thinking ability in integral calculus subject. International Journal of Education and Research, 2(12), 101-108.

Hardingdekam, J. L. (2007). Foundations in ethnomathematics for prospective elementary teacher. The Journal of Mathematics and Culture, 2(1), 1-20.

Hisrich, R. D., Bucar, B., \& Oztark, S. (2003). A cross-cultural comparison of business 
Jurnal Riset Pendidikan Matematika, 5 (2), 2018 - 210

Muchamad Subali Noto, Siska Firmasari, Mohammad Fatchurrohman

ethics: Case of Russia, Slovenia, Turkey and United States. Cross Cultural Management: An International Journal, 10(1), 3-28. doi:10.1108/13527600310797504

Jailani, J., Sugiman, S., \& Apino, E. (2017). Implementing the problem-based learning in order to improve the students' HOTS and characters. Jurnal Riset Pendidikan Matematika, 4(2), 247-259. doi:10.21831/jrpm.v4i2.17674

Joy, S., \& Kolb, D. A. (2008). Are there cultural differences in learning style? International Journal of Intercultural Relations, 33, 6985. doi:10.1016/j.ijintrel.2008.11.002

Melhem, T. Y. M., \& Isa, Z. M. (2013). Enhancing critical thinking skills among students with learning difficulties. International Journal of Academic Research in Progressive Education and Development, 2(4), 151-169.

Nfon, N. F. (2015). Ethnomathematics: The cultural aspects of secondary school mathematics in Cameroon. International Journal of Multidisciplinary Research Review, 2(1), 137-147.
Paraide, P. (2008). Number in the Tolai Culture. Contemporary PNG Studies DWU Research Journal, 9(2), 69-77.

Puspadewi, K. R., \& Putra, I. G. N. N. (2014). Etnomatematika di balik kerajinan Bali. Jurnal Matematika, 4(2), 80-89.

Rosa, M., \& Orey, D. C. (2009). Ethnomathematics: The cultural aspect of mathematics. Revista Latinoamericana de Etnomatematca, 4(2), 32-54.

Sternstein, M. (2008). Mathematics and the Dan Culture. The Journal of Mathematics and Culture, 3(1), 1-13.

Syahrin, M. A., Turmudi, T., \& Puspita, E. (2015). Study ethnomathematics of Aboge (Alif, Rebo, Wage) Calendar as determinant of the great days of Islam and traditional ceremony in Cirebon Kesepuhan Palace. AIP Conference Proceedings, 1708(1), 1-10. doi:http://dx.doi.org/10.1063/1.4941172

Ubayanti, S. U., Lumbantobing, H., \& Manurung, M. M. H. (2016). Eksplorasi etnomatematika pada Sero (Set Net): Budaya masyarakat Kokas Fakfak Papua Barat. Jurnal Ilmiah Matematika dan Pembelajarannnya, 2(1), 11-17. 